Ganechko Irina,

$\mathrm{PhD}$ in Economics, Associate Professor, Kyiv National University of Trade and Economics,

Kyiv, Ukraine

ORCID: 0000-0002-1918-3164

ResearcherID : M-7817-2016

Trubei Oksana,

$\mathrm{PhD}$ in Economics, Associate Professor, Kyiv National University of Trade and Economics,

Kyiv, Ukraine

ORCID: 0000-0003-4882-5813

ResearcherID : M-8541-2016

Parimal C. Biswas,

Adamas University,

Kolkata, West Bengal, India

ORCID: 0000-0002-3377-1878

\title{
STARTUP ECOSYSTEM: THE ESSENCE AND FEATURES OF DEVELOPMENT
}

The article analyzes the modern theoretical aspects of the startup ecosystem, which is formed at the local and global levels. The author's interpretation of the concept of "startupecosystem» is offered, the composition of the subjects of its life support and the basic elements are specified. On the basis of the latest international rankings the tendencies of development of the world startup ecosystem were investigated. The peculiarities of development of the startup environment in Ukraine were characterized.

Keywords: startup, startup ecosystem, innovative ecosystem, ecosystem actors, development of startup ecosystem.

Ганечко Ірина, Трубей Оксана, Парімал Чандра Бісвас. Стартапекосистема: сутніть та ообливоті розвитку.

У статті аналізуються сучасні теоретичні аспекти стартап-екосистеми, яка формується на локальних та глобальному рівнях. Запропоновано авторське тлумачення поняття «стартап-екосистема», уточнено склад суб'єктів ї̈ життєзабезпечення та основні елементи. На основі даних останніх міжнародних рейтингів досліджено тенденцій розвитку світової стартап- 
екосистеми та охарактеризовано особливості розбудови середовища стартапів в Україні.

Ключові слова:стартап, стартап-екосистема, інноваційна екосистема, суб'єкти екосистеми, розвиток стартап-екосистеми.

Relevance of the research topic. The innovation potential of the state depends on many factors. In today's context, it is the public's inclination to innovate and technology; availability of a large number of enterprises specializing in the production of high-tech products; existence of appropriate educational institutions, research centers; high-level of innovative culture of the population and business communities; a wide network of institutional forms of interaction between participants of the innovation process. All this forms a unique ecosystem in which innovative ideas can be implemented in a short period of time and with a relatively small financial investment a startup ecosystem. Therefore, it is relevant to research the startup ecosystem, its essential elements, status, local and global development trends, and the experience of the best startup ecosystems.

Formulation of the problem. The above arguments sharpen scientific interest in the issues of building a startup ecosystem as a powerful factor in the economic development of any state. That is why it is necessary to analyze the existing approaches and clarify the scientific interpretation of the concept of startup ecosystem, its components and peculiarities of the development of economic environment of startups, both internationally and at the level of individual countries and cities.

Analysis of recent research and publications. In the scientific and economic literature, attention is mainly paid to the study of theoretical and practical bases of formation and development of innovative and entrepreneurial ecosystems. Many foreign and domestic scientists covered this topic in their works: Bramwell A., Brachik H., Wang P., Liedesdorf L., Sable K., Smorodinskaya N., Varnaliy Z., Marchenko O., Fedulova L., and others. Research of start-ups as subjects of innovative activity, stages of their life cycle, factors of success, viable business models, sources of financing are devoted to work of foreign scientists, in particular Blanc S. [3], Damodaran A., Graham P., Ries E. [9], Thiel P. [13] and others. Conditions for forming an effective startup ecosystem in selected countries are reviewed in the works of Bahree M. [2], Deeb G. [4], Yin D. [14].

In Ukraine, the number of scientific papers devoted to the study of the content, structure, current state and directions of development of the startup ecosystem is quite limited, due to the short history of the startup movement and the lack of information base for research. The startup ecosystem as a subsystem of the innovative ecosystem, which is aimed at creating innovative products and services for startup companies, is devoted to the work of Sytnik N. [10]. Practical aspects of start-ups, ecosystems of their functioning and development in Ukraine are covered by domestic entrepreneurs- 
innovators, business coaches: Babich M. [1], Dovgopoly D., Babiachok R., Peir I., Tigipko V.

Presenting main material. The use of the analogy method allows the use of common terminology in different sciences. This also applies to our term «ecosystem», one of the major categories of biology and ecology. This term was first proposed in 1935 by the English ecologist A. Tensley, who understood under the ecosystem the totality of living organisms and their habitat, forming a single whole with it. In 1989, the American scientists Frosch R. and Gallopoulos N. coined the term «industrial ecosystem» applying it to the economy. In the 1990s, Rothschild states that «a capitalist economy can best be comprehended as a living ...», and JF Moore introduced the term «entrepreneurial ecosystem» [8]. From the same time, the terms «innovative ecosystem» and startup ecosystem were firmly included in the business lexicon.

In recent years, the startup movement has been a factor in the economic growth of many countries in the world. In conditions of rapid development of technologies of innovation act as drivers of productivity, competitive advantages, growth of cost of business, economic and social growth of the countries.

Startups have the opportunity to create a fast and very profitable business that has a short life cycle. According to Steve Blank, a startup is looking for a profitable, resilient and scalable business model [3]. Given the specifics of the organization and timing of the startups, you can define a startup as a temporary structure with a short cycle of entry to the market, which is under development and is based on innovative ideas or technologies that have just emerged.

Understanding the particular role of startups, governments and municipal authorities are launching tax incentives for startup development; big business representatives provide financial and technical assistance to startups, search for young talents, form their motivation system, develop their own business accelerators and innovation centers; business incubators are created; international conferences and forums will be organized, the central theme of which is the field of technological entrepreneurship. In this way, ecosystems are emerging in different countries around the world, without which the process of developing startups is not possible.

Translating the concept of ecosystems from the natural sciences to the economy, we can consider the startup ecosystem as an open dynamic system, which consists of an interconnected set of entities, united by a broad network of internal and external links involved in the process of creating and developing business activities based on innovative ideas or new technologies to find a profitable business scalable model.

One can agree with Sytnik N., who views the startup ecosystem as a subsystem of the innovative ecosystem, aimed at creating innovative products and services for startup companies [10].

Elements of the startup ecosystem include a set of interconnected entrepreneurial actors, organizations (e.g. firms, venture capitalists, business angels 
and funds), institutions (universities, public sector agencies and financial bodies), and processes (business birth rate, number of serial entrepreneurs, and levels of entrepreneurial ambition).

Key players in the startup ecosystem are:

- Entrepreneurs. Important experience of participants who have knowledge and skills in management, marketing, technology, finance.

- Business coaches. Experienced innovation leaders help you get through the startup all the steps and not repeat the mistakes of others.

- Business Incubators / Business Accelerators. Provide mentoring support, workplaces to implement ideas, assist with the search for investors.

- Investors. Business Angels, Venture Funds, Private Companies, Government or Minority Innovation Funds provide funding for startups at various stages and reduce the time to market.

- Universities / Research organizations. A large number of new business ideas were born as a result of research conducted at universities (academic entrepreneurship) or at research centers.

- Companies. Different companies can act as investors directly or through venture funds; are often potential leads of startups.

- Associations / Media. Many startup problems are solved through collaboration platforms that can be served by industry communities, professional associations, commodity exchanges, and more. Collaboration with such sites allows to advertise and find partners.

- State (municipal) organizations. Provision of tax incentives, financial support, licenses, protection of intellectual property rights, public events.

- Service providers. The development of startup ecosystems is accompanied by lawyers, bankers, accountants, various consultants, and their experience in working with startups improves the ecosystem itself.

All entities in a startup ecosystem are interconnected, perform different functions, or duplicate, but are aimed at solving specific problems of a startup.

The growth of communications in the startup ecosystem increases entrepreneurs' opportunities. The most important structural component of a startup ecosystem is people with their ideas, talents and entrepreneurial abilities. The startup ecosystem is formed under the influence of social, cultural (first of all, entrepreneurial culture), technological, political and other factors and exerts a negative influence on the environment.

Given the role of startups in the development of individual countries, different regions, cities, it is advisable to learn from the successful global experience of forming an ecosystem of startups in order to formulate a strategy and various forms of support for the startup movement. 
The global development of the startup movement has intensified research into the state, dynamics and tendencies of the development of startup ecosystems by geographical feature. Since 2014 the Startup Blink Research Center analyzes and compares startup ecosystems in different countries and cities, by publishing a corresponding Global Startup Ecosystem Ranking. In 2019, this study covered more than 100 countries and 1,000 cities worldwide [1]. The main purpose of this ranking is to create and demonstrate a global map of the global startup ecosystem and its evaluation.

Undoubtedly, the rating data are of considerable interest, both for the governments of individual countries and city administrations, and for the startups themselves. The development of the startup environment that creates the preconditions for attracting and retaining talents, making better entrepreneurship ecosystem and economic growth of individual regions and cities. Business, in turn, becomes more aware of the possibilities of implementing business ideas, meeting their basic needs.

The top 10 countries and cities in the world according to Global Startup Ecosystem Ranking 2019 are presented in Table 1 [6].

As the table shows, they rank at the top of the US, UK and Canada startups. At the same time, according to the Doing Business 2019 rating [5], New Zealand ranks first in terms of ease of doing business, Singapore second, Denmark third. The US is eighth, and Britain is only 9th. It is obvious that there is a discrepancy between the countries' rankings in the two major ratings of business. It can be assumed that not every country or city can satisfy the most important requirements of the startup ecosystem, in particular the availability of special infrastructure (business incubators, accelerators, techno parks, venture capital, etc.) and preferential business startups.

Table 1

Top 10 countries and cities in the world for startup ecosystem development in 2019

\begin{tabular}{|c|c|c|c|c|}
\hline Global rating & Country & Scores & City & Scores \\
\hline $\mathbf{1}$ & United States & 44.090 & San Francisco Bay, United States & 262.878 \\
\hline $\mathbf{2}$ & United Kingdom & 16.719 & New York, United States & 55.938 \\
\hline $\mathbf{3}$ & Canada & 15.867 & London, United Kingdom & 38.421 \\
\hline $\mathbf{4}$ & Israel & 14.626 & Los Angeles Area, United States & 34.219 \\
\hline $\mathbf{5}$ & Australia & 12.953 & Boston Area, United States & 33.946 \\
\hline $\mathbf{6}$ & Netherlands & 12.907 & Tel Aviv Area, Israel & 23.942 \\
\hline $\mathbf{7}$ & Sweden & 12.774 & Berlin, Germany & 22.322 \\
\hline $\mathbf{8}$ & Switzerland & 12.527 & Chicago, United States & 18.412 \\
\hline $\mathbf{9}$ & Germany & 12.461 & Seattle, United States & 18.107 \\
\hline $\mathbf{1 0}$ & Spain & 12.396 & Moscow, Russia & 17.504 \\
\hline
\end{tabular}


From this perspective, the experience of countries that are actively improving their startup ecosystems is interesting. This is particularly true of Israel and India, which have significantly improved their global ranking. Yes, Israel (4th place), despite the difficult geopolitical situation, was able to build a strong business ecosystem. The country with a population of 8.7 million has one startup for every 1,400 people. For comparison, in the UK, France and Germany $-0.21,0.11$ and 0.06 respectively. Over the last decade, the country has gained valuable experience selling its companies to foreign techno-giants. At the same time, many startups headquartered in Israel are turning into large, successful multinationals without leaving their homeland. Among them, in particular, Cybereason ( $\$ 100$ million), Vayyar ( $\$ 45$ million), Airobotics (\$32.5 million) [11].

India ranks 17th in the global rankings and is the fourth largest technology startup in the world. Experts estimate that their numbers can grow to 11500 by 2020 . The capital of the Indian startup ecosystem is the city of Bangalore, often called the Indian Silicon Valley due to the high concentration of large IT companies. The city has about 4,000 active tech startups. The level of venture investments and the number of successful startups has been increasing lately. More recently, the Indian startup ecosystem has been a branch of startups in other countries, but today it has become an environment in which startups are supported and successfully developed [12].

Table 2

Cities of Ukraine in the Global Startup Ecosystem Ranking

\begin{tabular}{|c|c|c|c|}
\hline \multicolumn{2}{|c|}{ Global rating } & \multirow{2}{*}{ City } & $\begin{array}{c}\text { Number of } \\
\text { Points, 2019 }\end{array}$ \\
\cline { 1 - 2 } 2019 & 2017 & Kiev & 11.711 \\
\hline $\mathbf{3 4}$ & 63 & Odessa & 6.185 \\
\hline $\mathbf{2 3 5}$ & 517 & Lviv & 2.876 \\
\hline $\mathbf{2 9 9}$ & 273 & Kharkiv & 2.644 \\
\hline $\mathbf{4 3 5}$ & 877 & Dnepro & 0.828 \\
\hline $\mathbf{5 6 1}$ & 1064 & Ternopil & 0.822 \\
\hline $\mathbf{6 7 8}$ & new & Donetsk & 0.815 \\
\hline $\mathbf{8 4 1}$ & 1118 & Boryspil & 0.812 \\
\hline $\mathbf{8 7 1}$ & new & & \\
\hline
\end{tabular}

One of the breakthroughs in the rating can be considered the capital of Ukraine Kyiv, where there are currently 321 startups. In the previous rating, Kyiv was ranked 63rd and climbed 29 positions immediately ahead of such large ecosystems as Helsinki, Munich, Shenzhen and Dublin. Other cities in Ukraine have rather low rating positions, although the positive dynamics of change are obvious.

In general, the domestic startup ecosystem is in its infancy, and the environment for the development of technological projects is not actually formed. According to entrepreneur M. Babich, each group of participants in the startup industry is interested solely in their specific interests: entrepreneurs only master the first steps of building 
startups, and investors are only able to finance the business in the later stages. According to the expert, Ukraine should build its own startup ecosystem with its integration into the global startup space. In particular, this involves establishing relations with foreign experts, investors, seeking opportunities to enter the US and European markets [1].

Despite the difficult economic and political situation, the startup ecosystem in Ukraine continues to emerge. The basis for its development may be the domestic IT industry, which is one of the three industries with the largest share in the gross domestic product of the country. Also, there is an active program of support for innovation and startups at universities in Ukraine. In particular: Sikorsky Challenge Business Incubator, established in 2014 at NTUU «KPI»; Tech StartUp School (1100 sq.m. of comfortable innovative environment for production and realization of creative ideas and successful startups) was created in 2017 at Lviv Polytechnic National University; the largest business incubator development project for Ukrainian educational institutions is the YEP Academic Business Incubator Network. In addition, there are incubators, startup school and accelerators created with the participation of private investors, foreign grant programs or organizations: UNIT Factory; GrowthUp Accelerator and Venture Fund; Startup Depot and Startup School University Edition; iHUB; Radar Tech; 1991 Open Data Incubator; Center for Entrepreneurship at UCU Lviv Business School; AgroHub and others [7].

Thus, one can clearly observe the main features of the startup ecosystem in Ukraine, its gradual formation and development. However, for its full functioning, many obstacles and difficulties have to be overcome. Their identification and analysis can be a promising avenue for further scientific research.

Conclusion. Summarizing the above, it can be argued that the startup ecosystem is an integral part of the business environment of any country. Its main purpose is to create the most favorable conditions for the rapid and efficient implementation of innovative and technological business projects. Special International Ranking statistics demonstrate the rapid global development of the startup ecosystem, which is reaching more and more countries and regions. Individual states and cities form their own approaches and tools in competing for talents and inventions in the world market. Ukraine may well become an active participant in the international startup community, subject to appropriate legal and financial support from the state and local governments. However, the most important solution remains the issue of political and economic stability in the country as key factors for increasing the investment attractiveness of domestic startup projects.

\section{REFERENCES}

1. Babich, M. (2016). Startups: Ecosystem in Ukraine. (Startapy: Ekosystema v Ukraini). Retrieved from http://blog.babich.me/search/label/ 
2. Bahree, M. (2018). Silicon Valley Firm Says India's Startup Ecosystem Is Afflicted By Huge Opportunity Gap. Forbes. Retrieved from https://www.forbes.com/ sites/meghabahree/2018/12/10/silicon-valley-firm-says-indias-startup-ecosystem-isafflicted-by-huge-opportunity-gap/\#27fa023b68e4

3. Blanк, S. (2013). Startup. Founder's board book. (Startap. Nastolnaia kniha obozrevatelia). Moskow. Alpine Publishing. 616 p. (rus).

4. Deeb, G. (2019). How To Build A Startup Ecosystem. Forbes. Retrieved from: https://www.forbes.com/sites/georgedeeb/2019/04/04/how-to-build-a-startupecosystem/\#645ab92a6130

5. Doing Business 2019. (2019). Retrieved fromhttps://www.doingbusiness.org/

6. Global Startup Ecosystem Ranking 2019. (2019). Retrieved from https://www.startupblink.com/

7. The main tendencies of development of startups in Ukraine - problems, obstacles, opportunities.(2018). (Osnovni tendentsii rozvytku startapiv v Ukraini problemy, pereshkody, mozhlyvosti). Retrieved from https://www.civic-synergy.org.ua/ wp-content/uploads/2018/04/Osnovni-tendentsiyi-rozvytku-startapiv-v-Ukrayini-1-1.pdf

8. Peltoniemi, M., Vuori E. (2008). Business ecosystem as the new approach to complex adaptive business environments. Retrieved from http://www.iwoce.org/ definitionsof-ecosystems.pdf.

9. Ries, E. TheLearnStartup. (Startap bez pomylok). Harkiv. Vivat Publishing. 2016. 368 p. (ukr).

10. Sytnyk, N. (2017). Startup ecosystem as a component of innovative ecosystem. (Ekosystema startapiv yak skladova innovatsiinoi ekosystemy). BIZNES INFORM. №8. P. 89-94. Retrieved from http://www.business-inform.net/export_ pdf/business-inform-2017-8_0-pages-89_94.pdf. (ukr).

11. Startup Nation and Its Unicorns: How Israel Created One of the Most Powerful Business Ecosystems. (Startap-nacii ta ii jedynorogy: jak Izrayl' stvoryv odnu z najpotuzhnishyh biznes-ekosystem). (2019). Retrieved from https://ufuture.com/uk/ startap-natsiya-ta-yiyi-yedinorogi-yak-izrayil-stvoriv-odnu-z-najpotuzhnishih-biznesekosistem/

12. Asian startups. Features of Asian startups. (2018). (Startapy Azyy. Osobennosty azyatskykh startapov). Retrieved from https://malbusiness.com/startapyiazii-osobennosti-aziatskih-startapov/

13. Thiel, P. (2016). Zero to one. Notes on Startups, or How to Build the Future. (Vid nulia do odynytsi. Notatky pro startapy, abo yak stvoryty maibutnie). Kiyv. Nash format. 224 p. (ukr).

14. Yin, D. (2017). What Makes Israel's Innovation Ecosystem So Successful. Forbes. Retrieved from https://www.forbes.com/sites/davidyin/2017/01/09/whatmakes-israels-innovation-ecosystem-so-successful/\#4c34a38a70e4 